University of Nebraska - Lincoln

DigitalCommons@University of Nebraska - Lincoln

USDA National Wildlife Research Center - Staff Publications
U.S. Department of Agriculture: Animal and Plant Health Inspection Service

2014

\title{
Efficacy of Plastic Mesh Tubes in Reducing Herbivory Damage by the Invasive Nutria (Myocastor coypus) in an Urban Restoration Site
}

Trevor R. Sheffels

Portland State University, trevor_sheffels@fws.gov

Mark D. Sytsma

Portland State University

Jacoby Carter

U.S. Geological Survey, carterj@usgs.gov

Jimmy D. Taylor II

USDA/APHIS/WS National Wildlife Research Center, jimmy.d.taylor@usda.gov

Follow this and additional works at: https://digitalcommons.unl.edu/icwdm_usdanwrc

Part of the Life Sciences Commons

Sheffels, Trevor R.; Sytsma, Mark D.; Carter, Jacoby; and Taylor, Jimmy D. II, "Efficacy of Plastic Mesh Tubes in Reducing Herbivory Damage by the Invasive Nutria (Myocastor coypus) in an Urban Restoration Site" (2014). USDA National Wildlife Research Center - Staff Publications. 1585.

https://digitalcommons.unl.edu/icwdm_usdanwrc/1585

This Article is brought to you for free and open access by the U.S. Department of Agriculture: Animal and Plant Health Inspection Service at DigitalCommons@University of Nebraska - Lincoln. It has been accepted for inclusion in USDA National Wildlife Research Center - Staff Publications by an authorized administrator of DigitalCommons@University of Nebraska - Lincoln. 
Trevor R. Sheffels $\mathbf{s}^{\mathbf{1 , 2}}$, and Mark D. Sytsma, Portland State University, Environmental Science and Management Department, Portland, Oregon 97207

Jacoby Carter, U.S. Geological Survey, National Wetlands Research Center, Lafayette, Louisiana 70506

and

Jimmy D. Taylor, United States Department of Agriculture, Animal and Plant Health Inspection Service, Wildlife Services, National Wildlife Research Center, Oregon Field Station, Corvallis, Oregon 97331

\title{
Efficacy of Plastic Mesh Tubes in Reducing Herbivory Damage by the Invasive Nutria (Myocastor coypus) in an Urban Restoration Site
}

\begin{abstract}
The restoration of stream corridors is becoming an increasingly important component of urban landscape planning, and the high cost of these projects necessitates the need to understand and address potential ecological obstacles to project success. The nutria (Myocastor coypus) is an invasive, semi-aquatic rodent native to South America that causes detrimental ecological impacts in riparian and wetland habitats throughout its introduced range, and techniques are needed to reduce nutria herbivory damage to urban stream restoration projects. We assessed the efficacy of standard Vexar® plastic mesh tubes in reducing nutria herbivory damage to newly established woody plants. The study was conducted in winter-spring 2009 at Delta Ponds, a 60-ha urban waterway in Eugene, Oregon. Woody plants protected by Vexar® tubes demonstrated $100 \%$ survival over the 3 -month initial establishment period, while only $17 \%$ of unprotected plantings survived. Nutria demonstrated a preference for black cottonwood (Populus balsamifera ssp trichocarpa) over red osier dogwood (Cornus sericea) and willow (Salix spp). Camera surveillance showed that nutria were more active in unprotected rather than protected treatments. Our results suggest that Vexar ${ }^{\circledR}$ plastic mesh tubing can be an effective short-term herbivory mitigation tool when habitat use by nutria is low. Additionally, planting functionally equivalent woody plant species that are less preferred by nutria, and other herbivores, may be another method for reducing herbivory and improving revegetation success. This study highlights the need to address potential wildlife damage conflicts in the planning process for stream restoration in urban landscapes.
\end{abstract}

Key words: herbivory, Myocastor, non-native, riparian, Vexar

\section{Introduction}

Streams and associated buffers are vital components of urban landscapes that provide ecological, social, and economic ecosystem services. Aquatic corridors are crucial for maintaining biodiversity and landscape connectivity at local and regional scales (Naiman et al. 1993) for fish, wildlife, macroinvertebrate, and plant species. Urban stream corridors also fulfill many human needs, such as contact with nature, aesthetics, recreation, and opportunities for citizen participation (Matsuoka

\footnotetext{
${ }^{1}$ Author to whom correspondence should be addressed. Email: trevor_sheffels@fws.gov

${ }^{2}$ Current affiliation: Friends of Tualatin River National Wildlife Refuge, Sherwood, OR 97140
}

and Kaplan 2008). Stormwater management within stream corridors results in economic benefits associated with flood mitigation and water quality protection (Braden and Johnston 2004). As urbanization continues to increase worldwide, the conservation and restoration of these aquatic corridors is becoming an increasingly important consideration for urban landscape planning.

More than U.S. \$1 billion is spent on stream restoration efforts annually since 1990 in the United States alone (Bernhardt et al. 2005). Greater than $60 \%$ of the projects completed during this time frame were for endangered fish, primarily salmon (Oncorhynchus spp.), in the Pacific Northwest and California (Katz et al. 2007). A primary component of these restoration projects is the reestablishment of riparian vegetation (Roni et 
al. 2002). Riparian vegetation buffers can reduce sediment inputs to the stream, moderate water temperature, stabilize stream banks, and provide habitat complexity (Osborne and Kovacic 1993). Typical costs to restore urban streams can range from $\$ 500-1,200$ per square foot (Kenney et al. 2012). This large financial investment suggests that obtaining information on potential obstacles to the success of stream restoration projects should be a priority (Rumps et al. 2007).

Mammalian herbivory is well-recognized as an important driver of ecological processes associated with plant community structure (Olofsson et al. 2004). For example, mammalian herbivores can alter succession patterns in both terrestrial (Davidson 1993) and aquatic (Gedan et al. 2009) systems. Mammalian herbivory is also known to impact plant diversity (Olff and Ritchie 1998). Herbivore feeding strategies are especially important to understand for habitat restoration where success is often dependent on the reestablishment of specific herbaceous and woody plant species. While much attention has been given to the negative ecological effects of livestock grazing on riparian habitats, particularly in western North America (Fleischner 1994, Belsky et al. 1999, Poff et al. 2011), wildlife herbivores in riparian zones also can pose major problems for restoration efforts (Opperman and Merenlender 2000). One such problem species for habitat restoration efforts throughout much of the world is the nutria (Myocastor coypus).

The nutria is a large, semi-aquatic, invasive rodent native to South America south of $23^{\circ}$ latitude (Ehrlich 1967, Woods et al. 1992). Nutria have been introduced worldwide over the last century for fur farming, and feral populations are now established on every continent except Australia and Antarctica (Carter and Leonard 2002). Nutria were introduced to the Pacific Northwest, United States, in the 1930s (Larrison 1943), and feral populations are expanding in both Oregon and Washington (Bounds 2000). Annual density estimates for introduced populations range from 1-25 nutria per hectare (Bounds et al. 2003), and high density populations can cause substantial ecological and economic damage through feed- ing and burrowing activities (LeBlanc 1994). The most studied impact has been the role of nutria herbivory in the loss of wetland and riparian structure and function, such as reduced plant biomass and sediment retention (Grace and Ford 1996, Carter et al. 1999, Johnson-Randall and Foote 2005, McFalls et al. 2010).

Nutria are generalist herbivore feeders able to consume up to $25 \%$ of their body mass daily by utilizing both aquatic and terrestrial plants (Gosling 1974, Guichón et al. 2003). Their diet can include all types of plant material, including leaves, stems, roots, and bark (Willner et al. 1979, Murua et al. 1981). Nutria are considered wasteful feeders, consuming as little as $10 \%$ of damaged plant material (Taylor et al. 1997). Nutria are known to over-utilize preferred species (Borgnia et al. 2000), but are able to change food habits on a seasonal basis in conjunction with the availability of food sources (Wilsey et al. 1991). In Oregon, a nutria population was observed consuming 40 plant species in a wetland habitat, with willow (Salix spp.) representing an estimated $12 \%$ of the total diet (Wentz 1971).

While damage has not been well quantified, habitat restoration managers in the Pacific Northwest report that nutria populations are causing substantial herbivory damage to newly planted riparian vegetation (Sheffels and Sytsma 2007). It is important to understand the extent of this damage and whether effective damage mitigation tools are available. Our objectives were to 1) document the level of observed herbivory for which nutria were responsible at Delta Ponds, 2) determine whether nutria exhibit preferences among woody riparian plant species commonly used for regional habitat restoration and 3) assess the efficacy of standard Vexar ${ }^{\circledR}$ plastic mesh tubing in mitigating nutria herbivory damage to newly planted woody plants during their initial establishment phase.

\section{Study Area}

The study was conducted in the Delta Ponds urban waterway (latitude: $44^{\circ} 4^{\prime} 53^{\prime \prime} \mathrm{N}$, longitude: $\left.123^{\circ} 6^{\prime} 31^{\prime \prime} \mathrm{W}\right)$, located in Eugene, Oregon, United States. The regional climate is characterized by cool, wet winters and warm, dry summers. 


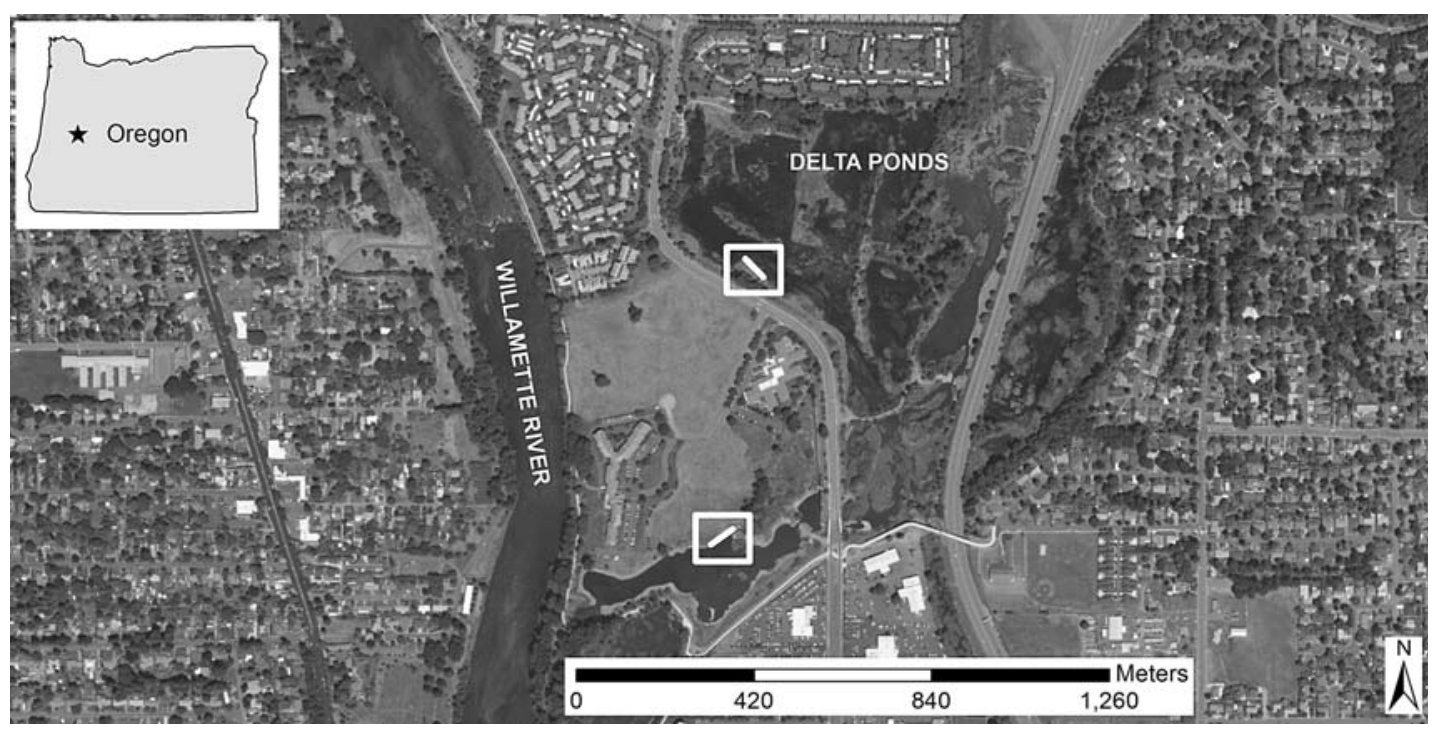

Figure 1. Aerial imagery depicting Delta Ponds urban waterway in relation to Willamette River to the west and urban development on all sides; lines (not to scale) delineated by boxes denote the two locations of vegetation transects established from February-May 2009.

Most of the $100 \mathrm{~cm}$ of annual precipitation falls between October and March (Oregon Climate Service 2012). Delta Ponds consists of 60 ha of connected ponds, channels, and associated riparian areas surrounded by development on all sides (Figure 1). A restoration project on the former gravel mining site was undertaken from 2004-2012 to reconnect the side channel to the adjacent Willamette River (Holts 2012). The primary project goal was to restore the natural hydrologic regime to provide rearing habitat for juvenile salmon species at Delta Ponds.

Reestablishing riparian woody plants was a key component of the restoration plan, but initial planting efforts were greatly hindered by losses to herbivores. A nutria control campaign in 2006 removed more than 70 nutria from the waterway during a 2-week trapping period (Lauri Holts, City of Eugene, personal communication). Although observed nutria activity at the site had diminished, a reproducing nutria population remained at Delta Ponds. A beaver (Castor canadensis) population was also present in the waterway, so the role of each species in the observed herbivory loss was unclear prior to our study.

\section{Methods}

Habitat restoration efforts at Delta Ponds included the construction of soil benches in three different areas within the site, but woody plants had not yet been installed on the benches prior to our study. We established a $24 \mathrm{~m}$ transect parallel to the water's edge at two of the locations to monitor nutria effects on newly established woody plants (Figure 1). The third bench was omitted due to a high level of human foot traffic. We planted the benches with live stakes of black cottonwood (Populus balsamifera ssp. trichocarpa), red osier dogwood (Cornus sericea), and willow (Salix spp.) collected from Delta Ponds and other nearby locations. These are three of the most common woody plant species used for wetland and riparian restoration in the Pacific Northwest because of the ability to harvest viable live stakes from existing trees and shrubs. Live stake planting followed standard methods (Sound Native Plants 2002) and was completed in February 2009.

The live stakes were planted on $0.6 \mathrm{~m}$ centers in three rows parallel to the water's edge for a total of 120 live stakes in each transect. Each species was randomly planted in proportions 


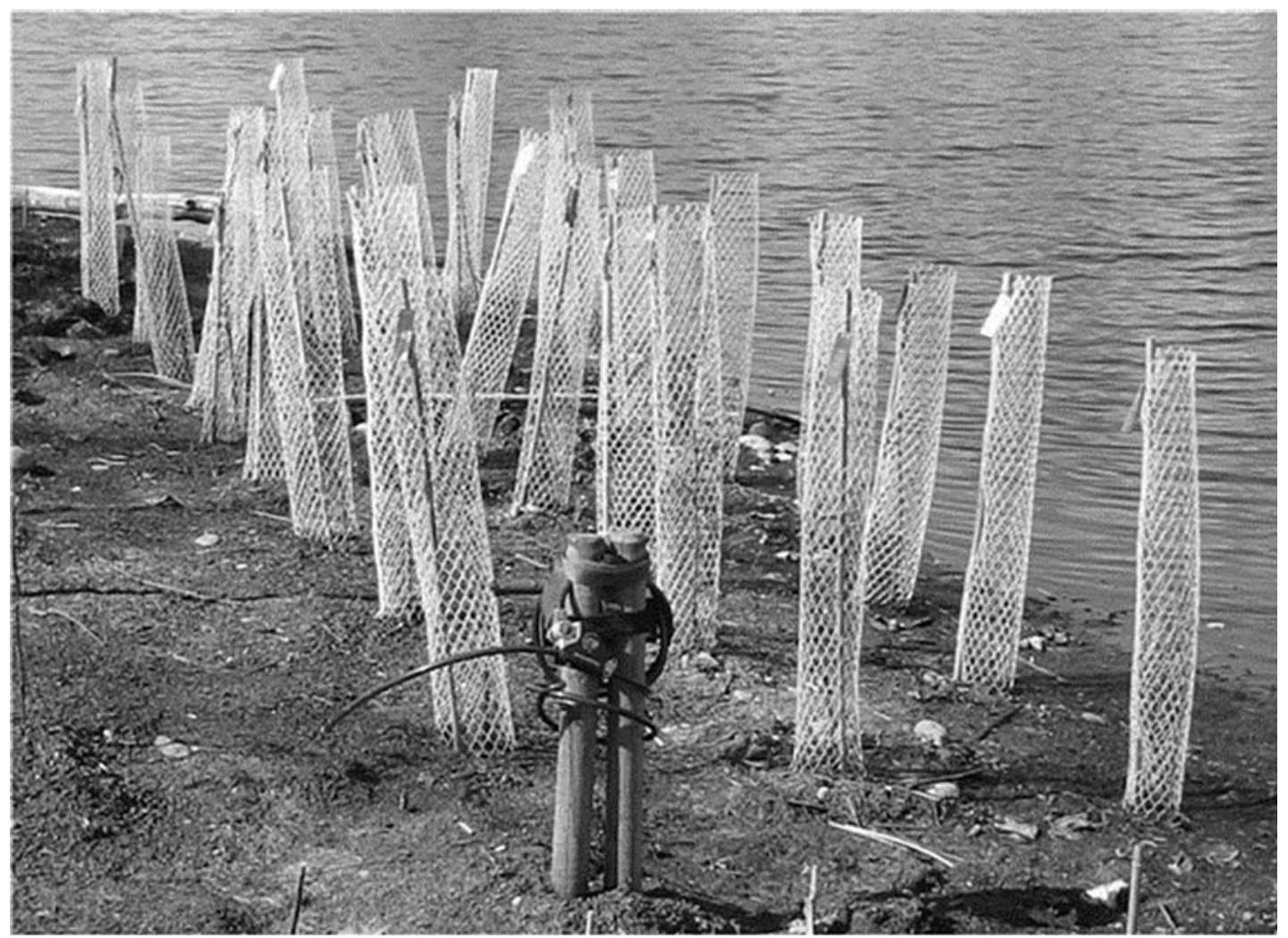

Figure 2. Transect segment of live stakes protected by Vexar® plastic mesh tubes and motion-activated surveillance camera station monitoring the segment from February-May 2009 within the Delta Ponds urban waterway.

that approximated those observed elsewhere in the Delta Ponds waterway. Overall proportions for planted live stakes were $0.48(n=116), 0.29$ $(n=69)$, and $0.23(n=55)$ for willow, red osier dogwood, and black cottonwood, respectively. Both transects were divided into four equal segments, each measuring $6.0 \mathrm{~m}$ in length, to compare nutria activity between treatments using video surveillance. Segments were oriented parallel with the planting rows, so each segment contained the three rows with 10 live stakes in each row for a total of 30 live stakes per segment. In each transect, two randomly selected segments were left unprotected while all live stakes in the other two segments were protected with individual barriers. We used standard Vexar® plastic mesh tubes to protect the woody plants from herbivory (Figure 2). Tubes were approximately $1.0 \mathrm{~m}$ in height and $100 \mathrm{~mm}$ in diameter. Each tube was stabilized by threading a single bamboo stake through the plastic mesh and anchoring it into the ground.

Individual live stakes within the vegetation transects were monitored throughout the study. Each live stake was given a unique ID number engraved in an aluminum tag staked next to the planting. An initial vegetation inventory was done concurrently with the live stake installation, and subsequent inventories were completed 9, 44, 94, and 100 days after installation. During each inventory, the status (alive vs. removed) of each live stake was recorded and Vexar® tubes were inspected for damage. Remaining plant material from destroyed live stakes was removed from the transects. We also monitored for signs (i.e., tracks and feces) of other herbivores during each inventory to determine whether any species other than nutria could be contributing to observed herbivory damage. 
We established infrared game cameras (Leaf River, model IR-3BU) to monitor nutria activity in each transect segment. One camera was placed at each transect segment along both transects for a total of eight cameras. Each camera monitored activity within a single transect segment, and there was no overlap in camera coverage between segments. The cameras were installed five days before live stake installation to assess baseline nutria activity 24 hours a day at the transect locations. Nutria were not observed in the daylight hours during this baseline period, so cameras were reprogrammed to be active only during nighttime hours during the study period to prevent excessive waterfowl camera triggers. Cameras were operational continuously during nighttime hours and were programmed to record 30 -second video clips to increase the likelihood of species identification.

All camera video clips were reviewed to quantify nutria activity within the study transects. A unit of nutria activity (i.e., independent nutria event) was defined as a record of nutria on a camera with no other documented nutria activity on that camera within a 0.5 -hour time frame. This unit of activity measurement was used to prevent over-representing the number of nutria visits to a transect segment when an individual remained in the near vicinity for an extended period of time. If multiple nutria were observed together on camera, the number of nutria events equaled the number of nutria observed simultaneously.

\section{Statistical Analysis}

We used a categorical analysis of variance model, with proportion of herbivory as the response function, to compare nutria herbivory on unprotected live stakes between each transect and species. The model response function is the inverse of proportion of plant survival, which is a nearly universal metric for evaluating plant establishment success in riparian restoration monitoring (Pollock et al. 2005). The segment parameter was collapsed into the transect parameter to decrease the number of sampling zeroes after initial modeling suggested segment did not influence the proportion of herbivory $(P>0.20)$. The final model consisted of transect and species as the fixed effects, and 0.5 was added to each cell to account for zero cells. Differences between species levels were assessed using pairwise chi-square analyses. A Pearson's chi-square goodness-of-fit test was used to assess nutria activity level between protected and unprotected transect segments within the south transect. Technical issues resulted in surveillance cameras at the north transect comprising less than $4 \%$ (31 of 832 ) of the total camera triggers, so the north transect was omitted from the nutria activity analysis. Poisson count confidence intervals for nutria activity were calculated using the Garwood method (Patil and Kulkarni 2012). Effect sizes were assessed by measuring relative risk (RR), which calculates the ratio of two probabilities (Grimes and Schulz 2008), since odds ratios could not be calculated for extreme survival probabilities equaling 0.0 or 1.0 .

\section{Results}

Live stakes protected by Vexar® tubing were 6.0 times $(\mathrm{RR}=6.0)$ more likely to survive $(95 \% \mathrm{CI}=$ 4.0-9.0, $P<0.001)$ than unprotected live stakes. In fact, the overall survival probability for protected plantings $(n=120)$ was 1.0 compared to 0.17 for unprotected plantings $(n=120)$. Herbivory damage in the unprotected transect segments resulted in live stakes being completely removed from the ground before root systems could become established. Both camera and physical evidence (e.g., teeth marks on live stakes, feces within transects) suggested that nutria were responsible for the observed plant damage (Figure 3). Damage to Vexar ${ }^{\circledR}$ plastic mesh tubing was not observed through video surveillance or physical inspection.

The categorical analysis of variance model (Table 1) showed that the proportion of herbivory on unprotected live stakes was influenced by plant species $(P<0.001)$ and transect $(P=0.046)$. There was less herbivory on willow than both red osier $\operatorname{dog}$ wood $(P=0.027)$ and black cottonwood $(P<$ $0.001)$. Overall, black cottonwood was 1.4 times (1.2-1.7) and 1.1 times (1.0-1.2) more likely to be removed than willow and red osier dogwood, respectively. This trend was more pronounced when the species-specific temporal patterns of 


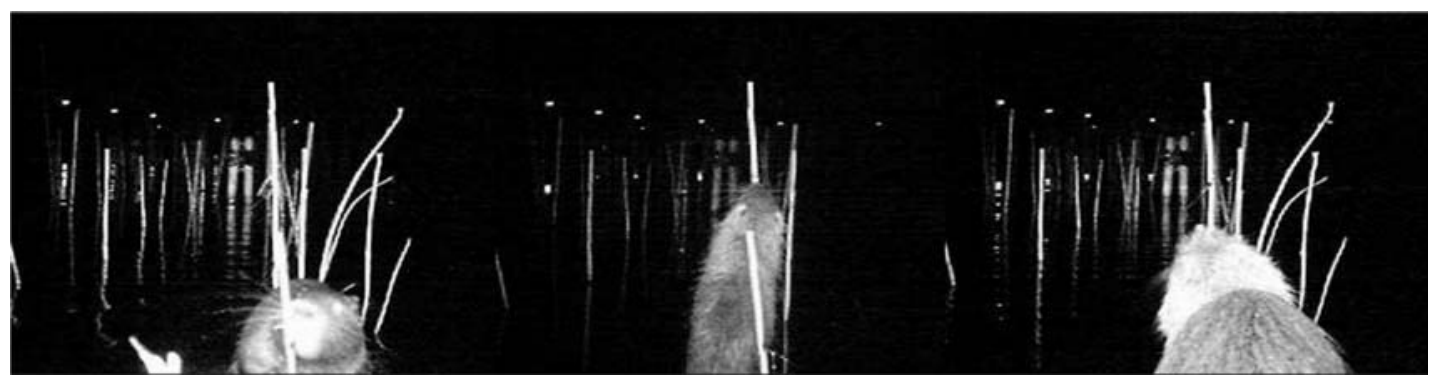

Figure 3. Examples of a motion-activated surveillance camera station capturing nutria targeting live stakes in an unprotected vegetation transect segment from February-May 2009 within the Delta Ponds urban waterway.

TABLE 1. Analysis of variance table showing the effect of model parameters (transect and species), and pairwise contrasts (in italics) comparing levels within species parameter, on the proportion of herbivory on unprotected live stakes from February-May 2009 within the Delta Ponds urban waterway complex in Eugene, OR.

\begin{tabular}{|c|c|c|c|c|c|}
\hline Parameter & $\mathrm{df}$ & Estimate & SE & Chi-Square & $P$ \\
\hline Intercept & 1 & 0.8432 & 0.0288 & 858.84 & $<0.0001$ \\
\hline Transect & 1 & $-\ldots$ & -- & 4.00 & 0.0455 \\
\hline North & & -0.0575 & 0.0288 & 4.00 & 0.0455 \\
\hline Species & 2 & $-\cdots$ & $-\cdots$ & 16.30 & 0.0003 \\
\hline COT & & 0.1245 & 0.0341 & 13.32 & 0.0003 \\
\hline WIL & & -0.1510 & 0.0457 & 10.92 & 0.0010 \\
\hline COT-WIL & 1 & - - - & $-\cdots$ & 15.84 & $<0.0001$ \\
\hline$C O T-R O D$ & 1 & - - - & - - - & 2.62 & 0.1054 \\
\hline$W I L-R O D$ & 1 & -- & - - - & 4.89 & 0.0269 \\
\hline Transect $\times$ Species & 2 & -- & -- & 3.49 & 0.1751 \\
\hline North COT & & 0.0586 & 0.0341 & 2.95 & 0.0861 \\
\hline North WIL & & -0.0096 & 0.0457 & 0.04 & 0.8337 \\
\hline Residual & 0 & & & & \\
\hline
\end{tabular}

COT $=$ black cottonwood

$\mathrm{WIL}=$ willow species

ROD $=$ red osier dogwood

live stake fate were considered. Within the first nine days following plant installation, black cottonwood was 5.5 times (2.7-11.3) and 6.9 times (2.7-17.9) more likely to be removed than willow and red osier dogwood, respectively. In fact, nutria removed $72 \%$ of black cottonwood live stakes $(n$ $=29)$ within the first 9 days compared to $13 \%$ and $11 \%$ for willow $(n=53)$ and red osier dogwood $(n$ $=38$ ), respectively. After 44 days, $100 \%$ of black cottonwood live stakes were removed compared to $70 \%$ and $87 \%$ for willow and red osier dogwood, respectively. Only a single red osier dogwood live stake was removed between days 44-100. Overall survival probabilities by species for unprotected plantings ranged from $0.00-0.30$ (Table 2). The north transect sustained less herbivory damage than the south transect $(P=0.046)$, as live stakes

TABLE 2. Survival proportions by transect for unprotected willow (WIL), red osier dogwood (ROD), and black cottonwood (COT) live stakes within the Delta Ponds urban waterway in Eugene, OR, from February-May 2009

\begin{tabular}{|c|c|c|c|c|c|c|}
\hline \multirow[b]{3}{*}{ Species } & \multicolumn{6}{|c|}{ Transect } \\
\hline & \multicolumn{2}{|c|}{ North } & \multicolumn{2}{|c|}{ South } & \multicolumn{2}{|c|}{ Overall } \\
\hline & Prop. & $\bar{n}$ & Prop. & $n$ & Prop. & $\bar{n}$ \\
\hline WIL & 0.37 & 27 & 0.23 & 26 & 0.30 & 53 \\
\hline ROD & 0.22 & 18 & 0.00 & 20 & 0.11 & 38 \\
\hline COT & 0.00 & 15 & 0.00 & 14 & 0.00 & 29 \\
\hline Overall & 0.23 & 60 & 0.10 & 60 & 0.17 & 120 \\
\hline
\end{tabular}


in the south transect were 1.2 times (1.0-5.7) more likely to be removed than in the north transect.

Nutria activity within the south transect was influenced by plant treatment. Only two nutria visits were recorded in the 5-day period before live stakes were planted. In the 100-day period after plant installation, nutria were 1.8 times (1.3-2.4, $P=0.003)$ more likely to be active in unprotected transect segments compared to protected segments. The overall proportion of nutria activity (i.e., independent nutria events) was 0.64 (0.55-0.88, $n$ $=70$ ) in unprotected segments compared to 0.36 $(0.28-0.53, n=39)$ in protected segments. The rate of nutria activity in unprotected segments increased starting day 7 after plant installation, and a similar pattern was observed in protected segments starting day 25 (Figure 4). Nutria activity rate decreased in protected segments beginning day 44 , but remained stable in unprotected segments until activity ceased after day 69 . Nutria activity in protected segments ceased after day 84 .

All evidence suggested that nutria were solely responsible for observed herbivory during the

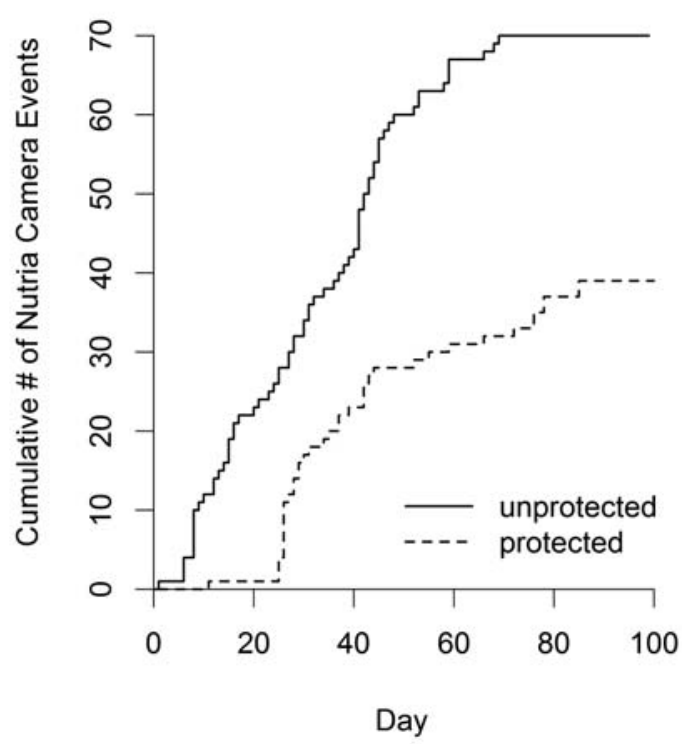

Figure 4. Cumulative number of independent (more than 0.5 hours between camera records) nutria events captured on surveillance cameras from FebruaryMay 2009 in protected and unprotected vegetation transect segments within the Delta Ponds urban waterway. study. While game camera technology did not allow us to quantify the total number of herbivory events or the proportion of nutria visits in which live stake removal occurred, nutria were regularly observed on camera targeting live stakes. American beavers (Castor canadensis) were photographed on seven occasions, but were not observed targeting live stakes. During transect surveys, we found no signs (i.e., tracks and feces) of ungulates (Family Cervidae) or other herbivores undocumented by cameras. Canada geese (Branta canadensis), mallards (Anas platyrhynchos), and raccoons (Procyon lotor) were regularly observed $(n>30)$ by camera surveillance, but not observed targeting planted live stakes.

\section{Discussion}

Nutria at Delta Ponds targeted live stakes soon after they were planted. Most studies from other regions have concluded that woody plant food sources represent a small proportion of the overall nutria diet (Shirley et al. 1981, Wilsey et al., 1991, Prigioni et al. 2005); however, terrestrial plants can comprise up to $35 \%$ of the nutria diet in their native range (Borgnia et al. 2000) and nearly $100 \%$ of the diet in some non-native urban habitats (Jacoby Carter, U.S. Geological Survey, personal observation). A study conducted in the Willamette Valley, Oregon, reported that willow was the most targeted plant species and comprised $12 \%$ of the nutria diet (Wentz 1971). It should be noted that Wentz (1971) conducted physical observations rather than fecal or stomach content analysis, so the proportion of floating and submerged aquatic vegetation in the diet was likely underrepresented. Kuhn and Peloquin (1974) also reported nutria damage to a variety of tree species in the Willamette Valley. Our results from Delta Ponds support the conclusions of Wentz (1971) and Kuhn and Peloquin (1974) that nutria populations in the Pacific Northwest regularly utilize available woody plants as part of their diet.

This study provides the first evidence that nutria prefer black cottonwood over other common wetland and riparian woody plants. Although only 29 black cottonwood live stakes were left unprotected, these plantings were more heavily 
targeted in the first nine days than the more abundant willow and red osier dogwood live stakes. Even though the proportion of live stakes removed was high for all species by the end of the 100-day period, black cottonwood was the only species to be completely removed from the unprotected transect segments. This pattern occurred in both transects even though the overall proportion of woody plants removed was lower in the north transect than the south transect. These observations suggest that other woody plant species functionally equivalent to black cottonwood should be utilized for revegetation planting when nutria herbivory is a potential concern.

There are several possible explanations for the observed difference in the proportion of herbivory between the two transects. Nutria activity level could have differed between the transects, but unfortunately the failure of camera surveillance equipment within the north transect prevented a quantitative comparison of nutria activity between transects. The spatial orientation of segment plant treatments within the transects also could have played a role. For example, the random assignment of treatment within the south transect resulted in live stakes being protected in the outer two segments and unprotected in the middle two segments. This layout could have potentially funneled nutria to the unprotected plantings and resulted in the higher herbivory level observed in the south transect. While it may not be realistic to use a completely randomized design when restoration is the primary objective, future herbivory studies should consider plot design as a potential confounding factor. A final possible explanation for the observed transect effect is that there was actually no practical effect or even no effect (i.e., false positive). This explanation is supported by the lower confidence interval comparing the relative risk of herbivory between transects equaling 1.0.

Vexar® plastic mesh tubing effectively protected woody live stakes from nutria herbivory damage during the 3-month initial establishment phase. Our results were contrary to those reported by Conner and Toliver (1987) in Louisiana. They concluded that Vexar® mesh tubes were ineffective at mitigating nutria herbivory damage to baldcypress (Taxodium distichum) seedlings after
$75 \%$ of the protected plantings, compared to $79 \%$ of unprotected plantings, were destroyed by nutria over the same 3-month time frame. Conner and Toliver (1987) also reported that nutria systematically chewed through the base of the plastic mesh to access the seedlings. We documented nutria regularly investigating live stakes protected by Vexar® tubes, but there was no video or physical evidence of nutria attempting to chew through the plastic mesh in our study.

A possible explanation for the difference in our results to those of Conner and Toliver (1987) is the difference in habitat use by nutria between the studies. Delta Ponds contained limited physical evidence (e.g., burrows, runs) of nutria activity. Even camera surveillance only documented less than one nutria visit per night to the south transect, which demonstrated higher live stake loss than the north transect, over the course of the study. While this rate of activity was dependent on how we defined a unit of activity, our anecdotal observations suggested that relative habitat use by nutria at Delta Ponds was low two years after the control effort. Conversely, Conner and Toliver (1987) documented a high number of nutria feeding platforms, indicating a higher relative habitat use in the Louisiana study. The difference in habitat use between Delta Ponds and Louisiana could be a function of a higher nutria population density in Louisiana; however, population density was not determined in either study. Other factors (e.g. intermittent inundation of transects at Delta Ponds vs. constant inundation of plots in Louisiana) also could have contributed to the different results.

Nutria activity patterns in protected and unprotected transect segments suggest that nutria targeted the most easily accessible woody plants. Nutria activity occurred almost exclusively in unprotected segments for the first 24 days after live stake installation. Nutria then shifted approximately $50 \%$ of their activity to the protected segments, presumably after the most preferred plantings in the unprotected segments had been utilized, for the next 20 days. Interestingly, nutria activity in protected segments then decreased even though a vast majority of the remaining woody plants were located in these segments. A possible explanation 
is that nutria shifted to alternative food sources outside the protected segments that provided higher energy intake per unit time, as described by optimal foraging theory (MacArthur and Pianka 1966). The eventual disappearance of nutria from both protected and unprotected segments provides further evidence that the remaining live stakes were less desirable than other food sources at Delta Ponds. It should be noted that nutria may have chewed through the mesh tubes, as reported by Conner and Toliver (1987) in Louisiana, if alternate food sources were scarce or habitat use by nutria was higher at Delta Ponds.

Though the Delta Ponds study was conducted on a small spatial and temporal scale, the selective herbivory and adaptive relative habitat use patterns by nutria that we observed mirrored those documented for other vertebrate herbivores. Time and energy are known to play a major role in food preference (Emlen 1966). For example, white-footed mice (Peromyscus leucopus) in natural habitats consistently selected food according to metabolic profitability (Lewis et al. 2001). In terms of habitat use, a proportional relationship exists between the amount of time spent in an area and the available quantity and quality of food (Bailey et al. 1996). Sullivan et al. (2007) reported that the relative habitat use by two mammalian herbivores, mule deer (Odocoileus hemionus) and moose (Alces alces), was higher in commercially thinned forest stands because understory vegetation was more abundant. These examples strengthen the conclusion that woody plants protected by Vexar® tubes at Delta Ponds, regardless of plant species, were not as attractive to nutria as other available food sources.

The establishment and subsequent protection of woody plants are crucial to the success of riparian corridor restoration projects (Roni et al. 2002). While other studies have suggested the use of Vexar® tubes in upland forest habitats to protect replanting efforts from species ranging from voles to deer (Pauls 1986, Engeman et al. 1999, Johnson and Okula 2006), this study is the first to our knowledge to document effective short-term use of $\operatorname{Vexar}{ }^{\circledR}$ for revegetation protection in a riparian habitat. The use of Vexar® plastic mesh tubes to mitigate herbivory damage is an attrac- tive option for restoration managers because it is non-lethal and most costs are up-front and likely minimal compared to the values of resources protected. While we demonstrated that mesh tubes can protect live stakes from nutria damage during the most critical initial months when live stake root systems are establishing, the efficacy of these barriers for long-term protection in an aquatic environment remains to be determined.

This study highlights the need to consider herbivore food habits when conducting habitat restoration activities in locations where herbivore populations are present. Our results provide information for restoration managers and planners facing nutria issues to evaluate when choosing appropriate woody plants for wetland and riparian restoration. Similar assessments for other mammalian herbivores could also prove valuable. Comparing our results to those of Conner and Toliver (1987) also highlights the potential importance of herbivore population management, either lethal or non-lethal, prior to riparian restoration work. As the rehabilitation of riparian corridors in both rural and urban landscapes continues to increase in scope, identifying and addressing potential wildlife damage concerns (e.g., herbivory) should be incorporated into the planning process. This added component of landscape planning is particularly important in the Pacific Northwest region, where riparian restoration is crucial for the recovery of federally listed anadromous fish species.

\section{Acknowledgements}

We would like to thank the people who provided resources and guidance for the project. Lauri Holts, City of Eugene Parks and Open Space, provided logistical guidance, supplied live stakes, and coordinated volunteer support. Sharon Gross, USGS Invasive Species Program, and Paul Heimowitz, USFWS Aquatic Invasive Species Program, provided funding for the study. Darren Johnson, USGS National Wetlands Research Center, provided statistical support. Comments from two anonymous reviewers and the journal editing team greatly improved the manuscript. Any use of trade, firm, or product names is for descriptive purposes only and does not imply endorsement by the U.S. Government. 


\section{Literature Cited}

Bailey, D. W., J. E. Gross, E. A. Laca, L. R. Rittenhouse, M. B. Coughenour, D. M. Swift, and P. L. Sims. 1996. Mechanisms that result in large herbivore grazing distribution patterns. Journal of Range Management 49:386-400.

Belsky, A. J., A. Matzke, and S. Uselman. 1999. Survey of livestock influences on stream and riparian ecosystems in the western United States. Journal of Soil and Water Conservation 54:419-431.

Bernhardt, E. S., M. A. Palmer, J. D. Allan, G. Alexander, K. Barnas, and S. Brooks. 2005. Synthesizing U.S. river restoration efforts. Science 308:636-637.

Borgnia, M., M. L. Galante, and M. H. Cassini. 2000. Diet of the coypu (Nutria, Myocastor coypus) in agro-systems of Argentinean pampas. Journal of Wildlife Management 64:354-361.

Bounds, D. L. 2000. Nutria: an invasive species of national concern. Wetland Journal 12:9-16.

Bounds, D. L., M. H. Sherfy, and T. A. Mollett. 2003. Nutria. In G. A. Feldhamer, B. C. Thompson, and J. A. Chapman (editors), Wild Mammals of North America: Biology, Management, and Conservation, Second Edition. The Johns Hopkins University Press, Baltimore, MD. Pp. 1119-1147.

Braden, J. B., and D. M. Johnston. 2004. Downstream economic benefits from storm-water management. Journal of Water Resources Planning and Management 130:498-505.

Carter, J., A. L. Foote, and L. A. Johnson-Randall. 1999. Modeling the effects of nutria (Myocastor coypus) on wetland loss. Wetlands 19:209-218.

Carter, J., and B. P. Leonard. 2002. A review of the literature on the worldwide distribution, spread of, and efforts to eradicate the coypu (Myocastor coypus). Wildlife Society Bulletin 30:162-175.

Conner, W. H., and J. R. Toliver. 1987. Vexar seedling protectors did not reduce nutria damage to planted baldcypress seedlings. Tree Planters' Notes 38:26-29.

Davidson, D. W. 1993. The effects of herbivory and granivory on terrestrial plant succession. Oikos 68:23-35.

Ehrlich, S. 1967. Field studies in the adaptation of nutria to seasonal variations. Mammalia 31:347-360.

Emlen, J. M. 1966. The role of time and energy in food preference. American Naturalist 100:611-617.

Engeman, R. M., R. M. Anthony, V. G. Barnes, H. W. Krupa, and J. Evans. 1999. Evaluations of plastic mesh tubes for protecting conifer seedlings from pocket gophers in three western states. Western Journal of Applied Forestry 14:86-90.

Fleischner, T. L. 1994. Ecological costs of livestock grazing in western North America. Conservation Biology 8:629-644.

Gedan, K. B., C. M. Crain, and M. D. Bertness. 2009. Small-mammal herbivore control of secondary succession in New England tidal marshes. Ecology 90:430-440.

Gosling, L. M. 1974. The coypu in East Anglia. Transactions of the Norfolk and Norwich Naturalists Society 23:49-59.

Grace, J. B., and M. A. Ford. 1996. The potential impact of herbivores on the susceptibility of the marsh plant Sagittaria lancifolia to saltwater intrusion in coastal wetlands. Estuaries 19:13-20.

Grimes, D. A., and K. F. Schulz. 2008. Making sense of odds and odds ratios. Obstetrics and Gynecology 111:423-426.

Guichón, M. L., V. B. Benítez, A. Abba, M. Borgnia, and M. H. Cassini. 2003. Foraging behavior of coypus Myocastor coypus: why do coypus consume aquatic vegetation? Acta Oecologica 24:241-246.

Holts, L. 2012. Delta Ponds floodplain restoration project summary. City of Eugene Parks and Open Space. Available online at http://www.eugene-or.gov/ DocumentCenter/Home/View/5890 (accessed 29 October 2012).

Johnson, R. G., and J. P. Okula. 2006. Antelope bitterbrush reestablishment: a case study of plant size and browse protection effects. Native Plants Journal 7:125-133.

Johnson-Randall, L. A., and A. L. Foote. 2005. Effects of managed impoundments and herbivory on wetland plant production and stand structure. Wetlands 25:38-50.

Katz, S. L., K. Barnas, R. Hicks, J. Cowen, and R. Jenkinson. 2007. Freshwater habitat restoration actions in the Pacific Northwest: a decade's investment of habitat improvement. Restoration Ecology 15: 94-505.

Kenney, M. A., P. R. Wilcock, B. F. Hobbs, N. E. Flores, and D. C. Martínez. 2012. Is urban stream restoration worth it? Journal of the American Water Resources Association 48:603-615.

Kuhn, L. W., and E. P. Peloquin. 1974. Oregon's nutria problem. In W. V. Johnson (editor), Proceedings of the 6th Vertebrate Pest Conference, Anaheim, CA. Pp. 101-105.

Larrison, E. J. 1943. Feral coypus in the Pacific Northwest. The Murrelet 24:3-9.

LeBlanc, D. J. 1994. Nutria. In S. E. Hygnstrom, R. M. Timm, and G. E. Larson (editors), Prevention and control of wildlife damage. University of Nebraska Cooperative Extension, Lincoln. Pp. B71-80.

Lewis, C. E., T. W. Clark, and T. L. Derting. 2001. Food selection by the white-footed mouse (Peromyscus leucopus) on the basis of energy and protein contents. Canadian Journal of Zoology 79:562-568.

Matsuoka, R. H., and R. Kaplan. 2008. People needs in the urban landscape: analysis of Landscape and Urban Planning contributions. Landscape and Urban Planning 84:7-19. 
MacArthur, R. H., and E. R. Pianka. 1966. On optimal use of a patchy environment. The American Naturalist 100:603-609.

McFalls, T. B., P. A. Keddy, D. Campbell, and G. Shaffer. 2010. Hurricanes, floods, levees, and nutria: vegetation responses to interacting disturbance and fertility regimes with implications for coastal wetland restoration. Journal of Coastal Research 26:901-911.

Murua, R., O. Neumann, and I. Dropelmann. 1981. Food habits of Myocastor coypus in Chile. In Chapman, J. A., and D. Pursley (editors). Proceedings of the Worldwide Furbearer Conference (Volume 1), Frostburg, MD. Pp. 544-558.

Naiman, R. J., H. Decamps, and M. Pollock. 1993. The role of riparian corridors in maintaining regional biodiversity. Ecological Applications 3:209-212.

Olff, H., and M. E. Ritchie. 1998. Effects of herbivores on grassland plant diversity. Trends in Ecology and Evolution 13:261-265.

Olofsson, J., P. E. Hulme, L. Oksanen, and O. Suominen. 2004. Importance of large and small mammalian herbivores for the plant community structure in the forest tundra ecotone. Oikos 106:324-334.

Opperman, J. J., and A. M. Merenlender. 2000. Deer herbivory as an ecological constraint to restoration of degraded riparian corridors. Restoration Ecology 8:41-47.

Oregon Climate Service. 2012. Oregon climate, Corvallis. Available online at http://www.ocs.orst.edu/climateof-oregon (accessed 28 June 2012).

Osborne, L. L., and D. A. Kovacic. 1993. Riparian vegetated buffer strips in water-quality restoration and stream management. Freshwater Biology 29:243-258.

Patil, V. V., and H. V. Kulkarni. 2012. Comparison of confidence intervals for the Poisson mean. REVSTAT-Statistical Journal 10:211-227.

Pauls, R. W. 1986. Protection with Vexar cylinders from damage by meadow voles of tree and shrub seedlings in northeastern Alberta. In T. P. Salmon (editor), Proceedings of the 12th Vertebrate Pest Conference, San Diego, CA. Pp. 199-204.

Poff, B., K. A. Koestner, D. G. Neary, and V. Henderson. 2011. Threats to riparian ecosystems in western North America: an analysis of existing literature. Journal ohe American Water Resources Association 47:1241-1254.

Pollock, M. M., T. J. Beechie, S. S. Chan, and R. Bigley. 2005. Monitoring restoration of riparian forests. In P. Roni (editor), Monitoring stream and watershed restoration. American Fisheries Society, Bethesda, MD. Pp. 67-96.

Received 3 October 2013

Accepted for publication 12 May 2014
Prigioni, C., A. Balestrieri, and L. Remonti. 2005. Food habits of the coypu, Myocastor coypus, and its impact on aquatic vegetation in a freshwater habitat of NW Italy. Folia Zoologica 54:269-277.

Roni, P., T. J. Beechie, R. E. Bilby, F. E. Leonetti, M. M. Pollock, and G. R. Pess. 2002. A review of stream restoration techniques and a hierarchical strategy for prioritizing restoration in Pacific Northwest watersheds. North American Journal of Fisheries and Management 22:1-20.

Rumps, J. M., S. L. Katz, K. Barnas, M. D. Morehead, R. Jenkinson, S. R. Clayton, and P. Goodwin. 2007. Stream restoration in the Pacific Northwest: analysis of interviews with project managers. Restoration Ecology 15:506-515.

Sheffels, T., and M. Sytsma. 2007. Report on nutria research and management in the Pacific Northwest. Portland State University, Center for Lakes and Reservoirs. Available online at http://www.clr. pdx.edu/docs/CLR_nutria_report.pdf (accessed 10 March 2008).

Shirley, M. G., R. H. Chabreck, and G. Linscombe. 1981. Foods of nutria in fresh marshes of southeastern Louisiana. In Chapman, J. A., and D. Pursley (editors). Proceedings of the Worldwide Furbearer Conference (Volume 1), Frostburg, MD. Pp. 517-530.

Sound Native Plants. 2002. About live stakes and cuttings. Available online at http://www.soundnativeplants. com/PDF/Cuttings\%20info\%20sheet.pdf (accessed 1 December 2012).

Sullivan, T. P., D. S. Sullivan, P. M. Lindgren, and D. B. Ransome. 2007. Long-term responses of ecosystem components to stand thinning in young lodgepole pine forest-IV. Relative habitat use by mammalian herbivores. Forest Ecology and Management 240:32-41.

Taylor, K. L., J. B. Grace, and B. D. Marx. 1997. The effects of herbivory on neighbor interactions along a coastal marsh gradient. American Journal of Botany 84:709-715.

Wentz, W. A. 1971. The impact of nutria (Myocastor coypus) on marsh vegetation in the Willamette Valley, Oregon. M.S. Thesis, Oregon State University, Corvallis.

Willner, G. R., J. A. Chapman, and D. Pursley. 1979 Reproduction, physiological responses, food habits and abundance of nutria on Maryland marshes. Wildlife Monographs 65:1-43.

Wilsey, B. J., R. H. Chabreck, and R. G. Linscombe. 1991. Variation in nutria diets in selected fresh water forested wetlands of Louisiana. Wetlands 11:263-278.

Woods, C. A., L. Contreras, G. Willner-Chapman, and H. P. Whidden. 1992. Myocastor coypus. Mammalian Species 398:1-8. 